\title{
6
}

\section{SENTIDOS DE GREVE NOS DISCURSOS DE MULHERES OPERÁRIAS}

\author{
STRIKE MEANINGS IN THE DISCOURSES \\ OF WORKING WOMEN
}

\author{
Mirella Moraes de Borba ${ }^{1}$ \\ Universidade Federal de Pelotas \\ Luciana Iost Vinhas ${ }^{2}$ \\ Universidade Federal de Pelotas
}

Resumo: Neste artigo nos propomos a discutir os efeitos de sentido produzidos pela palavra greve. A análise foi feita sob a perspectiva da Análise do Discurso pecheuxtiana. Para isso, analisamos sete entrevistas com mulheres operárias do setor têxtil que presenciaram a greve de 1984, na Fábrica Laneira Brasileira S.A. Nessas entrevistas, a palavra greve emerge em diferentes enunciados, produzindo efeitos de sentido distintos, que dependem da posição ideológica a partir da qual o sujeito enuncia. Nos enunciados analisados, os sujeitos resistem ao assujeitamento à ideologia dominante, por meio da greve, a qual é caracterizada como "muito divertida". Ao romper com os efeitos de sentidos anteriores, as operárias produzem um novo, que é resultado da resistência feita por elas.

Palavras-Chave: Análise do Discurso; Efeitos de sentido; Greve; Operárias.

1 Endereço eletrônico: borbamirella@gmail.com.

2 Endereço eletrônico: lucianavinhas@gmail.com. 
Abstract: In this article we propose to discuss the sense effects produced by the word strike. The analysis was made from the perspective of the Pecheuxtian Discourse Analysis. In order to achieve the objective of the article, we analyzed seven interviews with women who were workers in the textile sector. These women witnessed the 1984 strike at Fábrica Laneira Brasileira AS. In these interviews, the word strike emerges in different statements, producing different senses, which depend on the ideological position from which the subject enunciates. In the analyzed statements, the subjects resist to subject themselves to the dominant ideology, and this is achieved through the strike, which, in the statements produced by them, is characterized as "very fun". By breaking with the effects of previous senses, the workers produce a new one that is the result of the resistance made by them.

Keywords: Discourse Analysis; Sense effects; Strike; Female workers.

As greves fizeram e fazem parte das lutas das operárias e operários por melhores salários e condições de trabalho. Sem elas, possivelmente ainda teríamos um número alto de acidentes e mortes no interior das fábricas. No Brasil, no início do século XX, as leis trabalhistas não existiam, e, em função disso, as condições de trabalho eram aquelas estipuladas pelos patrões. As jornadas de trabalho podiam chegar a até 20 horas diárias e o direito de trabalhadores se organizarem em sindicatos era proibido. Diante da situação de exploração, a classe operária passou a fazer uso da sua arma mais eficaz: as greves. No decorrer do século $\mathrm{XX}$, as lutas da classe trabalhadora por condições mais humanas de trabalho se intensificaram e diversos direitos foram sendo adquiridos ao longo dos anos.

No dia $1^{\circ}$ de maio de 1943, o então presidente Getúlio Vargas sancionou o Decreto-Lei no 5.452, que trouxe mais direitos para todos os trabalhadores e trabalhadoras do país. Embora a implementação da CLT no Brasil tenha sido um grande avanço para a classe trabalhadora, as lutas por mais direitos não pararam, pois a classe trabalhadora continuava a ter um salário que mal cobria as despesas mais básicas para sua subsistência, principalmente no período da ditadura militar, no qual a inflação era altíssima e os salários não acompanhavam a elevação constante. Os testemunhos de mulheres operárias que serão analisados neste trabalho, apresentados a seguir, fazem referência a esse espaço de tempo, e a inflação é citada constantemente nesses depoimentos. 
Somente no ano de 1988 a assinatura da Constituição Federal passa a assegurar mais direitos trabalhistas, como a proteção contra a dispensa arbitrária ou sem justa causa; piso salarial proporcional à extensão e à complexidade do trabalho prestado; licença à gestante, sem prejuízo do emprego e do salário, com a duração de 120 dias; licença paternidade; irredutibilidade salarial; e limitação da jornada de trabalho para 8 horas diárias e 44 horas semanais.

Neste artigo, analisamos relatos sobre a primeira greve que aconteceu na Fábrica Laneira S.A., ocorrida no ano de 1984. A greve teve duração de dois meses e as trabalhadoras e os trabalhadores se organizaram junto ao sindicato do comércio (pois, na época, ainda não existia Sindicato dos Trabalhadores nas Indústrias e Cooperativas da Alimentação de Pelotas) para reivindicar a continuidade da jornada de trabalho de seis horas diárias, já que a administração queria aumentar a jornada para oito horas diárias sem o respectivo aumento no salário. A análise se debruça em trechos de entrevistas com mulheres operárias que trabalharam na fábrica durante o período da greve, seguindo os princípios teóricos da Análise do Discurso Materialista (AD).

A greve em questão ocorreu na cidade de Pelotas/RS, que é conhecida historicamente pela produção de alimentos. Inicialmente, a produção de charque impulsionou o desenvolvimento da cidade no início do século XIX, época em que a cidade chegou a ter 35 estabelecimentos de comercialização desse produto, abatendo mais de cinco milhões de cabeças de gado entre os anos de 1871 e 1885. Já no final do século XIX e início do século XX, as charqueadas entram em declínio, abatendo 1.837.095, entre os anos de 1905 e 1919, contando apenas com cinco estabelecimentos de comercialização de charque, segundo a revista “Almanach" de Pelotas, no ano de 1920 (ESSINGER, 2009).

Com os lucros adquiridos pela indústria saladeril no século XIX e como consequência do aproveitamento dos produtos descartados pelas indústrias charqueadoras, a alternativa encontrada foi atrair outras indústrias para a cidade 
de Pelotas, como curtumes, fábricas de velas, sabões e adubos, utilizando os resíduos da indústria da carne. Além disso, foram feitos investimentos em lavouras de arroz e fruticulturas, o que diversificou o quadro industrial da cidade formando, assim, um núcleo que, mais tarde, se tornou muito importante para a industrialização da cidade.

Os testemunhos aqui analisados são parte de uma coletânea de entrevistas realizadas no período de 2017 até 2019 como parte do projeto de pesquisa "Mulheres Laneiras: um inventário das memórias femininas da Fábrica Laneira Brasileira S.A." (BORBA, 2019), desenvolvido no Programa de Pós-Graduação em Memória Social e Patrimônio Cultural da Universidade Federal de Pelotas. A partir do arquivo dessa pesquisa, foram selecionados cinco recortes dos depoimentos de diferentes operárias que falam sobre a greve da Fábrica Laneira S.A. Todas as operárias entrevistadas trabalhavam na Laneira durante a greve de 1984. Os recortes foram selecionados por demonstrarem uma regularidade discursiva a partir da temática da greve, e as operárias se posicionam tanto a favor quanto contra o movimento. Além disso, os relatos escolhidos trazem os diferentes efeitos de sentido produzidos sobre o imaginário de "greve".

Relatos sobre outras fábricas ${ }^{3}$ dão conta de que as greves não eram comuns nas fábricas de Pelotas/RS no final do século $X X$, sendo que a greve da Laneira foi a única mencionada no total de quinze entrevistas com mulheres que trabalharam nas fábricas Laneira, Veiga, Agapê e no Curtume Herbert Hadler. Mesmo as operárias que nunca trabalharam na Laneira tinham conhecimento da greve em questão.

3 Era uma prática comum que as fábricas contratassem as operárias para trabalhar durante uma safra e, depois disso, as operárias eram demitidas. Isso fazia com que ocorresse uma grande circulação de mulheres entre as fábricas da cidade. A Fábrica Laneira era uma das únicas na cidade de Pelotas que tinha funcionárias fixas. Das nove mulheres entrevistadas da Laneira, sete já haviam trabalhado em outras fábricas anteriormente. 
As mulheres operárias entrevistadas trabalharam no setor industrial nas décadas de 1980 e 1990. As greves da cidade de Pelotas/RS nesse setor remetem às décadas de 1940 e 1950, período em que as indústrias passavam por graves crises econômicas, devido ao fechamento do Banco Pelotense. Sendo assim, as mulheres entrevistadas só participaram de uma greve no período em que trabalharam como operárias, e essa greve está marcada nos discursos das entrevistadas, que contam sobre os momentos compartilhados nesse período com os colegas de luta.

Não por acaso a greve em questão ocorreu na década de 1980, período em que Pelotas presenciou a falência consecutiva de muitas fábricas importantes para a economia da cidade. A Prefeitura, tentando amenizar o impacto econômico, lançou a Lei $\mathrm{n}^{\circ}$ 2.096, de 06 de dezembro de 1973, que criou o distrito industrial da cidade. Todavia, isso não surtiu grandes efeitos para a economia do município, que, atualmente, conta com muitos prédios industriais em completo abandono.

As demissões em massa, bem como o medo de perder o emprego devido ao fechamento das fábricas na região, também estão presentes nos relatos das operárias. Mesmo que a greve não tenha ocorrido por esse motivo, não se pode desconsiderar todo o contexto sócio-histórico vivido no período. Esses elementos fazem parte da história de vida das mulheres entrevistadas, uma vez que o fechamento das fábricas da região acarretou mudanças irreversíveis em suas carreiras, fazendo com que elas buscassem novos meios de se sustentarem.

Ressaltamos aqui que os relatos foram coletados quase trinta anos após a greve e a demissão das operárias, ou seja, os medos e os receios presentes nos seus dizeres já se concretizaram, deixando para o agora somente a lembrança, já transformadas pela passagem do tempo.

Os elementos apresentados até aqui fazem parte das condições de produção (CP) em que os sujeitos estão inseridos. Parafraseando Orlandi (2015), 
todo texto, considerado por meio de suas condições de produção, é um discurso. O discurso só existe porque determinado enunciado coloca em circulação saberes relacionados a um contexto sócio-histórico-ideológico. Para Pêcheux (2011, p. 151), a materialidade discursiva existe "enquanto nível da existência sóciohistórica, que não é nem a língua, nem a literatura, nem mesmo as "mentalidades" de uma época, mas remete às condições verbais de existência dos objetos em uma conjuntura dada". Ou seja, a conjuntura dada é determinante para a produção dos discursos dos sujeitos. A materialidade discursiva analisada neste artigo está ancorada nas CP vividas pelos sujeitos.

Dessa forma, as CP são fundamentais para compreender os testemunhos analisados neste artigo, uma vez que os sujeitos são afetados pelas condições de existência a que estão expostos. Os enunciados produzidos pelas entrevistadas mostram como a interpelação do sujeito se manifesta concretamente na língua, e essa interpelação ocorre à revelia do sujeito. Citamos, mais uma vez, Pêcheux (2011) que afirma:

Se o discurso é uma materialidade histórica sempre já dada, na qual os sujeitos são interpelados e produzidos como "produtores livres" de seus discursos cotidianos, literários, ideológicos, políticos, etc..., a questão primordial cessa de ser a da subjetividade produtora do discurso e torna-se a das formas de existência históricas da discursividade. (PÊCHEUX, 2011, p. 156)

Sendo assim, o processo de interpelação dos indivíduos em sujeitos está ligado ao contexto sócio-histórico-ideológico. A conjuntura apresentada é determinante para a forma como as mulheres se relacionam com a ideologia, uma vez que elas atravessaram décadas de luta por mais direitos trabalhistas, que foram alcançados já no final de suas carreiras ${ }^{4}$. Dessa forma, os discursos produzidos pelas operárias entrevistadas são afetados pelo passado de lutas já

4 Quase todas as entrevistadas se aposentaram na década de 1990. 
concretizadas e pelas lutas que ainda estavam por vir no momento da realização da greve, mas que, atualmente, já aconteceram.

Consideramos impossível trabalhar com o episódio da greve se não for pelo viés da resistência. A greve pode ser considerada um ato de resistência, uma vez que a classe dominada (operários e operárias) se rebela contra as condições de trabalho impostas pela classe dominante (proprietários da fábrica). A referência de Orlandi (1998, p. 17) sobre resistência afirma que "o processo de resistência é justamente isso: estabelecer um outro lugar de discurso onde se possa (re)significar o que ficou 'fora' do discurso", ou seja, colocar em circulação saberes que são silenciados pela gestão da ideologia dominante. Isso significa dizer que, na $\mathrm{AD}$, a resistência ocorre quando a ideologia dominada entra em choque com a ideologia dominante, quando ocorre uma luta entre as classes, sendo que esse processo pode ser materializado de diferentes formas. Contudo, para que ocorra o processo de resistência, é necessário que haja uma falha no processo de interpelação do sujeito, preparado pela ideologia dominante para se identificar com aquilo que pode e deve ser dito a partir dessa posição dominante. Segundo Pêcheux (2018):

- não há dominação sem resistência: primado prático da luta de classes, que significa que é preciso "ousar se revoltar".

- ninguém pode pensar do lugar de quem quer que seja: primado prático do inconsciente, que significa que é preciso suportar o que venha a ser pensado, isto é, é preciso "ousar pensar por si mesmo". (PÊCHEUX, 2018, p. 281)

A ideologia dominante sempre encontra resistência, pois não existe uma plena interpelação. A resistência surge justamente onde a falha se instala, sendo que é do inconsciente que emerge aquilo que infecta pelo funcionamento da interpelação ideológica, trazendo para o discurso aquilo que não se assujeita da ideologia dominante. Cabe frisar que Pêcheux (2018, p. 278) afirma que não se pode colocar o inconsciente como fonte da ideologia dominada, porque "a ordem 
do inconsciente não coincide com a da ideologia", mas uma não pode ser pensada sem referência à outra, por ser um processo dialético de constituição. Carvalho (2015, p. 122) resume que "a existência do inconsciente não tem, portanto, um fundamento ideológico; mas ele é ponto de tropeço a partir do qual se poderia fazer obstáculo à ideologia dominante".

Levamos em conta que a $\mathrm{AD}$ ensina que não se pode dizer tudo e que os sentidos sempre podem ser outros. Isso ocorre porque a língua não é transparente, em que "supõe-se que todo sujeito falante sabe do que se fala" (PÊCHEUX, 2012, p. 68); assim, caso fosse transparente, os significados seriam os mesmos para todos os sujeitos, fazendo parte do universo logicamente estabilizado. $\mathrm{Na} A \mathrm{D}$, a língua é dotada de opacidade e a equivocidade faz parte da estrutura da língua, sendo os deslizamentos e os descolamentos possíveis de ocorrer, pois os significados não estão colocados nas palavras, mas nas condições de existência dos sujeitos.

A produção dos efeitos de sentido passa pela compreensão dos processos históricos ocorridos na língua, ou seja, os sentidos são atribuídos em referências situacionais a outros discursos. A movência dos significantes se inscreve na língua por meio dos dizeres e confere sentidos diferentes a depender da situação em que determinada palavra, expressão, proposição é enunciada. Para Orlandi (2012, p. 30), “os sentidos não estão só nas palavras, nos textos, mas na relação com a exterioridade, nas condições em que eles são produzidos e que não dependem só das intenções do sujeito".

Trabalhar com os efeitos de sentido produzidos em torno da palavra greve é sempre partir do princípio da análise do discurso pecheuxtiana de que o sentido não está colado à palavra. $\mathrm{O}$ sentido depende das condições materiais em que o enunciado surge; assim, o artigo trabalhará sobre os efeitos de sentido estabelecidos considerando a posição a partir da qual o sujeito enuncia. Isso significa que, por ser atravessado pela ideologia e pelo inconsciente, os 
enunciados não são individuais do sujeito, mas resultados do processo de interpelação sofrido por ele.

As greves são direito fundamental dos trabalhadores, embora isso seja facilmente ignorado por aqueles que detêm o poder. A liberdade sindical é reconhecida como o primeiro dos "Princípios e Direitos Humanos Fundamentais do Trabalho", que fazem parte da declaração da Organização Internacional do Trabalho - OIT, datada de 1998.

Existem inúmeros estudos a respeito da teorização das greves enquanto um instrumento na luta de classes, sendo Engels e Marx os pioneiros a tratar sobre o assunto. Segundo Engels (2010), somente por meio da greve os trabalhadores conseguiriam adquirir mais direitos trabalhistas. Sobre o início dos movimentos grevistas, o autor afirma que:

Este movimento operário passa por diferentes etapas: A revolta individual, - o crime - pode ser uma das suas formas; a destruição de máquinas e outra, se bem que nenhuma destas duas formas esteja universalmente espalhada. O sindicalismo e a greve são as primeiras formas generalizadas que o movimento operário toma, e a sua importância assenta menos na sua eficácia do que na lição de solidariedade que dão: os trabalhadores adquirem nelas a consciência de classe. (ENGELS, 2010, p. 16)

A união dos trabalhadores para juntos reivindicarem condições mais justas de trabalho passa a ser um dos principais pontos para a tomada da consciência da classe operária. Essa tomada de consciência só ocorre quando a classe dominada se rebela contra a classe dominante, sendo essa subversão necessária para o desenvolvimento humano mais digno. A greve é a forma mais eficaz de luta da classe operária. Nas palavras de Engels (2010),

[...] os operários devem, portanto, procurar sair dessa situação que os embrutece, criar para si uma existência melhor e mais humana e, para isso, devem lutar contra os interesses da burguesia enquanto tal, que consistem precisamente na exploração dos operários. (ENGELS, 2010, p. 247) 
Ainda sobre a greve, Marx (S/D, p. 266) argumenta que ela é, na verdade, um movimento político que tem como "objetivo último a conquista do poder político para a classe operária". O autor afirma que as greves não devem ser um movimento econômico, pois a luta não é apenas para que determinada indústria não altere a carga horária de trabalho; a luta deve ser para que se decretem leis que proíbam o aumento da carga horária. Ele segue sua teoria de que:

todo movimento que a classe operária atua como classe contra as classes dominantes e trata de força-las "pressionando do exterior" é um movimento político [...] um movimento de classe cujo alvo é que se dê satisfação a seus interesses em forma geral. (MARX, S/D, p. 266)

Dessa forma, esclarece que a luta não é unicamente contra os patrões, mas contra as classes dominantes, contra o capitalismo de uma forma geral.

A greve da Laneira foi, portanto, um movimento político, pois os operários estavam pressionando os donos da fábrica a pagarem o que a lei determinava, que era um salário mínimo por seis horas de serviço corrido. A proposta dos proprietários era de pagar um salário mínimo em troca de oito horas de serviço diário, sendo que os trabalhadores teriam um intervalo de duas horas para o almoço e quinze minutos para o café. Os operários rejeitaram a proposta e entraram em greve por dois meses e, durante esse período, não receberam os salários. As famílias que dependiam exclusivamente do sustento da fábrica conseguiram, junto ao sindicato, doações de cestas básicas.

Os depoimentos aqui analisados fazem parte do arquivo de pesquisa desenvolvida por Borba (2019), sendo que a autora realizou entrevista narrativa aplicada com as ex-funcionárias da fábrica Laneira, de maneira individual.

Importante ressaltar que a entrevista narrativa é considera um método de pesquisa qualitativo, ou seja, a partir dela, busca-se entender o que aconteceu em determinado momento da vida do entrevistado, tendo como técnica a entrevista 
semi-estruturada, que proporciona às mulheres operárias entrevistadas uma fala e uma escuta sobre determinado momento das suas vidas.

Para esta análise, foram selecionados recortes sobre greve, sendo que todas as entrevistadas, em algum momento das conversas, relataram sobre a greve. A atenção foi direcionada para os dizeres que tentavam significar o movimento grevista.

Dentre as oito mulheres entrevistadas que trabalharam na Laneira no período em que ocorreu a greve, sete delas se posicionaram a favor da greve, e todas as sete disseram que a greve foi um momento importante para a conquista de direitos trabalhistas. Apenas uma das entrevistadas disse não ter participado da greve e foi trabalhar todos os dias normalmente, conforme consta na sequência discursiva (SD) 1.

$\mathrm{SD} 1 / \mathrm{T}^{5}$ - Eu não era contra nem a favor, eu só não aderi, uma porque eu precisava trabalhar e tava vendo aquela sujeirama lá que tava lá na frente, porque até o rapaz que era encarregado nosso um dia eu ia chegando eu e mais uma encarregada lá do Tops e ele nos xingou, mas tivemos que passar depois e entrar com a viatura da polícia, porque eles não deixavam, tavam fazendo um piquete.

No início da SD1, quando a entrevistada diz Eu não era contra nem a favor, eu só não aderi, se produz, conforme nosso gesto de interpretação, o efeito de sentido de que ela não queria se comprometer com os grevistas, tampouco julgava adequada a postura adotada pela empresa, dando a entender que não tinha um posicionamento sobre a greve, pois ela não estava de lado nenhum, "nem uma coisa, nem outra": nem do lado dos proprietários da fábrica, nem dos operários. É como se, ao não aderir à greve, ela permanecesse "neutra" frente à reivindicação feita pela categoria; no entanto, ela também poderia ter dito Eu não era contra nem a favor, eu só segui trabalhando. Ao seguir trabalhando, mesmo

\footnotetext{
5 A sigla significa que a Sequência Discursiva 1 foi retirada de entrevista realizada com a Trabalhadora 1. O mesmo formato foi adotado nas siglas empregadas em outras sequências do corpus da pesquisa.
} 
entendendo que não estava assumindo nenhuma posição frente ao movimento grevista, a trabalhadora obedece à determinação da indústria, não rompe com a indústria, o que mantém a relação de exploração e, por conseguinte, produz o efeito de uma adesão ao discurso reproduzido pela indústria. É como se a trabalhadora concordasse com as condições de trabalho impostas pelos empregadores, as quais não preveem o aumento do salário frente ao aumento da carga horária de trabalho.

Assim, ao não aderir à greve, a entrevistada toma partido pelo lado contrário ao dos colegas grevistas, pois a greve parte do princípio de forçar os chefes a acatarem suas reivindicações por meio da interrupção das atividades da fábrica. Ou seja, se os operários param a produção da fábrica, causam prejuízo econômico para a empresa: sem força produtiva não existem relações de produção. Quando alguém não adere à greve e não cessa suas atividades dentro da fábrica, o efeito de dar prejuízo fica comprometido e faz com que a greve perca o sentido, mantendo-se a posição assumida pelos empregadores como dominante.

Ao tentar se manter "neutra", ao "só não aderir" e ir trabalhar normalmente, a entrevistada se coloca contra a greve, pois prejudica os objetivos dos seus colegas de trabalho de parar com as atividades da fábrica totalmente. Dessa forma, temos aqui as duas posições antagônicas sobre os posicionamentos sobre a greve: aqueles a favor da greve e aqueles que são contra a greve.

A SD1 segue com porque eu precisava trabalhar; nesse ponto, a entrevistada apresenta o motivo para não entrar em greve, qual seja, a necessidade de seguir trabalhando, de seguir recebendo o salário, já que a sua força de trabalho é vendida para a empresa, e, por isso, se justificaria a necessidade de trabalhar. Nessa SD, a entrevistada, ao dizer que "precisava trabalhar", deixa de dizer que seus colegas de trabalho "não precisavam trabalhar", pois aderiram à greve. Para Orlandi (2015, p. 80), “o posto (o dito) traz consigo necessariamente esse 
pressuposto (não dito, mas presente)". Esse não-dito pressupõe que talvez ela acreditasse que aderir à greve significasse "não precisar trabalhar" e ela, diferentemente de seus colegas, precisava trabalhar (precisava vender a sua força de trabalho) e, por isso, não podia entrar em greve.

Sendo assim, não é dito que o "não trabalhar", o "aderir à greve", representavam para a entrevistada "não receber o salário". Ao dizer que "precisava trabalhar", ao invés de "precisava receber", exime a fábrica da responsabilidade de pagar os salários dos trabalhadores, sendo previsto em lei o direito à greve sem o corte dos salários.

Para a entrevistada, o salário está diretamente ligado com a troca de força de trabalho por dinheiro. Ela poderia ter dito que "precisava do dinheiro"; entretanto, disse que "precisava do salário", ou seja, ela não considera legítimo receber dinheiro sem trabalhar. Não é apenas uma questão de receber, mas de receber pelo seu trabalho; a entrevista é determinada, portanto, pela FD dominante, pois, caso tivesse feito greve, vinculada à dominação do modo de produção capitalista, teria exigido o pagamento do salário, como é de seu direito.

Mesmo que o relato sobre a greve acabasse no "precisava trabalhar", os dois trechos analisados seriam suficientes para perceber que a entrevistada, ao não ser nem a favor nem contra, ao precisar trabalhar, posicionava-se de forma contrária à greve, identificando-se, dessa forma, com uma formação discursiva (FD) capitalista, que antagoniza com a FD do trabalhador. Assim, com as análises aqui empreendidas, conseguimos compreender, a partir das materialidades em foco, o funcionamento de duas formações discursivas, a partir das quais é possível concordar com a greve para melhorar as condições de trabalho (FD do trabalhador) ou discordar da greve e manter as relações de produção com a exploração do trabalhador (FD capitalista).

Para Pêcheux (2018, p. 147, grifos do autor), FD "é aquilo que numa formação ideológica dada, isto é, a partir de uma posição dada numa conjuntura 
dada, determinada pelo estado da luta de classes, determina o que pode e deve ser dito", sendo que o assujeitamento ocorre pelo processo de identificação do sujeito com uma FD. Conforme citação de Indursky (2007, p. 306), que afirma que “é o indivíduo que, interpelado pela ideologia, se constitui como sujeito, identificando-se com os dizeres da formação discursiva que representa, na linguagem, um recorte da formação ideológica". Ou seja, a FD não pode ser pensada separadamente da interpelação ideológica do sujeito, pois a identificação com determinada FD está condicionada à ideologia.

Dessa forma, a entrevistada é assujeitada à ideologia dominante, vinculada a uma formação discursiva (FD) dominante de cunho capitalista, e se identifica, portanto, com essa FD capitalista, em que o sujeito acredita que o recebimento do salário deve prevalecer, mesmo que vá contra direitos trabalhistas. Nessa FD, a greve é "o não trabalhar", "o não receber salário", não sendo vista como um movimento legítimo de luta para a obtenção dos direitos previstos em lei. Fazer greve não é, a partir da posição da qual essa mulher fala, reconhecido como um movimento de luta, mas, sim, não trabalhar, e, consequentemente, não receber.

As operárias grevistas, por outro lado, se identificavam com a FD do trabalhador, reconhecendo-se enquanto mulheres trabalhadoras do setor industrial, e percebem que as fábricas tinham a obrigação de pagar os salários previstos em lei, já que elas, trabalhadoras, cumpriam com suas obrigações dentro da fábrica. Para elas, a greve é reconhecida como um movimento legítimo de luta, da qual as operárias e operários devem fazer uso sempre que tiverem seus direitos colocados em risco. Como veremos nos trechos a seguir, as operárias materializam, por meio dos enunciados selecionados, que eram contrárias ideologicamente às condições a que eram expostas, ou seja, contrárias às determinações da posição política, ideológica e de classe dominante. 
SD2-T7 - Na época da greve ainda não existia o sindicato, na verdade a gente se juntou e criou ele pros chefes não poderem nos colocar para rua. Foi muito legal durante a greve, a gente conseguiu aguentar firme e ter o que a gente pedia. [...] Depois que terminou a greve eles, nós fundamos o sindicato, para a gente se proteger, porque nós tava na linha de frente ali da greve. Então, de tempo trabalhado mesmo eu tive uns nove ou dez anos, mas de tempo na carteira foram treze, porque depois eu fui suspensa. [...] Fiquei uns quatro anos sem trabalhar, mas com a carteira assinada e recebendo.

Na SD2, a entrevistada fala sobre a necessidade de criação do sindicado da indústria na cidade de Pelotas após a greve, denunciando que o término da greve não foi pacífico, e que, embora os proprietários da fábrica tenham cedido às reivindicações dos grevistas, isso não ocorreu sem represálias. A criação do sindicato trouxe para as operárias segurança para que elas pudessem reivindicar seus direitos sem o medo da demissão.

No enunciado $\mathrm{Na}$ época da greve ainda não existia o sindicato, na verdade a gente se juntou e criou ele pros chefes não poderem nos colocar para rua, percebemos que a criação do sindicado é uma forma de resistência que a ideologia dominada encontra para poder continuar lutando contra a ideologia dominante. No entanto, isso acontece nos termos da ideologia dominante, ou seja, de acordo com as leis criadas pela ideologia dominante, que é uma ideologia de cunho burguês, cujas legislações são também burguesas. Apesar disso, a criação do sindicato pode ser compreendida como uma forma de resistência à ideologia dominante, mesmo que isso seja vinculado a um reformismo ao invés de ser vinculado ao processo revolucionário.

As operárias buscavam com a greve e a criação do sindicato uma transformação nas relações de produção. Conforme Pêcheux (2014):

Colocar-se "sob o ponto de vista da reprodução" no primado da luta de classes é, necessariamente, colocar-se, ao mesmo tempo, sob o ponto de vista de quem se opõe a essa reprodução, sob o ponto de vista da resistência a essa reprodução e da tendência revolucionária à transformação das relações de produção. (PÊCHEUX, 2014, p. 03) 
A resistência surge do desejo de mudar, de se rebelar, de transformar as relações de produção, que, no caso analisado, mudaram no momento em que o chefe não pôde colocar a operária para a rua, pois esta faz parte do sindicato, e demitir alguém do sindicato é contra a lei, sendo a própria greve um ato de resistência ao não se aceitar o que os proprietários da fábrica impõem. A criação do sindicato, com a motivação de manter os empregos dos grevistas, explicita que se manter empregado e ter um salário é fundamental para as operárias e operários grevistas.

Outro ponto de resistência referido à SD2 está nos efeitos de sentido do discurso sobre a greve, como se percebe na formulação Foi muito legal durante a greve, a gente conseguiu aguentar firme e ter o que a gente pedia. Assim, a greve não carrega só os sentidos de luta e de dificuldades. Ela, também, "foi muito legal", ou seja, "conseguir aguentar firme" foi muito legal, "ter o que a gente pedia" foi muito legal: a greve foi muito legal. $\mathrm{O}$ "legal" aqui, segundo nossa interpretação, produz o efeito de sentido de que a greve foi boa, mas poderia, também, ter o sentido de legalidade, de estar dentro da lei. A greve foi legal em todos os sentidos. Foi legal resistir e garantir os direitos, mesmo que isso tivesse trazido algumas dificuldades às mulheres grevistas, como por exemplo a falta de salário durante a período da greve, o que fez com que elas tivessem que buscar ajuda para o recebimento de doações de comida.

Outro sentido atribuído à greve foi "a greve era divertida", como se vê nas sequências abaixo:

SD3-T6 - Quando teve a greve eu participei, eu ia com os outros colegas para tentar trancar o trabalho da fábrica, nós fazia passeata no centro, era divertido. Meu marido também participou da greve, mas na época nós não éramos namorados ainda. 
SD4-T5 - Bá! Aquela greve foi o máximo, nós fazia os piquete ali, na frente da Laneira. Foi muito bom. Teve quem não aderiu, mas nós não fizemos nada, quem jogou xixi foram os homens. Na época a gente ficou sem receber, eu já tinha até me separado, o dinheiro fez falta, mas no fim a gente conseguiu tudo. A greve foi muito divertida, nós ia pra lá cedo e ficava praticamente o dia todo lá, tomava chimarrão, fazia comida.

SD5-T9 - A greve foi muito divertida. Teve uma vez que eles queria sair com o caminhão cheio de lã dos japoneses, porque os japoneses era tudo no horário certo, aí a gente não deixou o caminhão sair, a gente sentou na frente do portão, eles não puderam sair. Depois disso eles tiveram que ceder.

Como pode ser observado nas três SD acima expostas, o "era divertido" aparece repetidas vezes nas falas de, no mínimo, três mulheres diferentes. Na SD4, a entrevistada se refere à greve como Aquela greve foi o máximo: a greve não foi simplesmente um movimento operário pela continuidade da carga horária de seis horas de trabalho, a greve foi o máximo, não foi só boa. Ao dizer que a greve foi o máximo, a entrevistada produz efeitos de sentido que rementem à FD do trabalhador, atualizando do interdiscurso saberes que são possíveis sobre a greve. Nesse caso, a greve foi o máximo, porque o resultado da greve foi a vitória para os operários. Isso é colocado no enunciado Na época a gente ficou sem receber, eu já tinha até me separado, o dinheiro fez falta, mas no fim a gente conseguiu tudo. A operária reconhece que o dinheiro fez falta, mas o importante foi conseguir tudo ao final - o importante foi garantir as condições de trabalho.

Os enunciados das sequências 3, 4 e 5, que entendem a greve como divertida, são um ato de resistência contra a ideologia dominante, pois mexem com os efeitos de sentido da palavra greve. Uma interpretação possível de ser realizada é a de que, para o empregador, uma greve não pode ser divertida - uma greve é representada como o oposto disso, já que gera prejuízo financeiro para o empregador. O sentido da palavra está, justamente, na FD com a qual o sujeito falante se identifica, tendo uma relação de dependência com o interdiscurso. Segundo Pêcheux (2018): 
[...] o próprio de toda formação discursiva é dissimular, na transparência do sentido que nela se forma, a objetividade material contraditória do interdiscurso, que determina essa formação discursiva como tal, objetividade material essa que reside no fato de que 'algo fala' (ça parle) sempre 'antes, em outro lugar e independentemente', isto é, sob a dominação do complexo das formações ideológicas. (PÊCHEUX, 2018, p. 149)

Sendo assim, os sentidos são ancorados pelos dizeres possíveis a partir de determinada FD; no caso em questão, os enunciados que dizem que a greve era divertida são produzidos por sujeitos identificados com a FD do Trabalhador e não por aqueles identificados com a FD capitalista, pois, para estes, a greve era um problema.

Dizer que a "greve foi muito divertida", como nas sequências 4 e 5, mexe com os efeitos de sentido da greve nos discursos dos operários; para aqueles que se identificam com a FD do trabalhador, a greve ser divertida representa muito mais do que dizer que a "greve não foi chata", ou, simplesmente, que a "greve foi boa", tendo ainda o intensificador de sentido "muito", isto é, não foi só "divertida", mas "foi muito divertida". A greve ser muito divertida é um dizer que não pode existir na FD capitalista, pois, para os que se identificam com ela, a greve foi um inconveniente, que atrapalhou os negócios da fábrica, trancou os serviços, o que acarretou na perda de dinheiro e na obrigação de ceder aos pedidos dos grevistas. Ao passar de uma FD para outra, a palavra pode ganhar sentidos diferentes. Na FD do trabalhador, a greve foi divertida; na FD capitalista, a greve não foi divertida.

Se divertir com a greve é resistir à ideologia dominante, é modificar os sentidos atribuídos à palavra. Dar outros sentidos, também, é uma forma de subversão. Nas palavras de Pêcheux (1990):

As resistências: não entender ou entender errado; não "escutar" as ordens; não repetir as litanias ou repeti-las de modo errôneo, falar quando se exige silêncio; falar sua língua como uma língua estrangeira que se domina mal; 
mudar, desviar, alterar o sentido das palavras e das frases; tomar os enunciados ao pé da letra; deslocar as regras na sintaxe e desestruturar o léxico jogando com as palavras... (PÊCHEUX, 1990, p. 17)

Esses deslizamentos em torno das palavras só ocorrem por causa da falha no processo de interpelação dos sujeitos. Produzir outros efeitos de sentido para a palavra greve é, portanto, um ato de resistência, uma vez que algo falha no processo de interpelação da ideologia dominante, que resulta em dizeres que só são possíveis por sujeitos identificados com a ideologia dominada.

A resistência, assim, ocorre quando existe uma falha no ritual de interpelação. A subversão é necessária para o sujeito, é parte inerente do processo de subjetivação deste. A falha no processo de interpelação ocorre nessa subversão de dizer algo que não se espera, de conferir um sentido outro para determinada palavra. Ao não ceder aos sentidos já atribuídos à palavra greve por aqueles que são os detentores do poder e produzir efeitos de sentido que dizem que a greve "foi muito divertida", subjetiva o sujeito como produtor de seu próprio discurso, enquanto operária/operário assujeitado à ideologia dominada, posicionado na resistência frente aos discursos de exploração da força de trabalho.

É nessas "mudanças de sentido" que o processo de interpelação do sujeito ocorre, sendo que é na FD em que o sujeito se inscreve que são capturados do interdiscurso os enunciados possíveis; os efeitos de sentido produzidos aqui são a materialização do assujeitamento sofrido por ele.

No caso analisado, as operárias e operários tecem a sua resistência por meio da não identificação com a reprodução das relações de produção, fazendo com que surjam outros sentidos à palavra greve, tornando-a "muito divertida", "legal", "o máximo". Esse deslocamento é resultado da resistência das operárias e operárias, em que foi preciso "ousar se revoltar" contra as mudanças arbitrárias nas condições de trabalho impostas pelos proprietários da fábrica. 
Outro ponto importante a ser destacado diz respeito à forma como os sujeitos-enunciadores fazem referência à primeira pessoa em seus depoimentos. Ao retomarmos a SD1, materializada pela operária que não aderiu à greve, observamos a recorrência do pronome pessoal eu na sua narrativa. Quando emprega a primeira pessoa do plural nós (uma única vez no recorte analisado), refere-se a ela e aos outros funcionários que não aderiram à greve. Por outro lado, as outras quatro mulheres entrevistadas dão privilégio ao emprego da primeira pessoa do plural, materializada pelo nós ou pelo a gente. Através dessa recorrência podemos compreender a determinação de saberes de coletividade na forma como essas mulheres se relacionam com a ideologia. Ao se colocarem no formato coletivo, conseguem se posicionar enquanto classe, e é daí que surgem efeitos de sentido de greve como algo divertido. Mesmo que não estejamos enfocando nossa análise no emprego dos pronomes pessoais, cabe realizar o comentário, pois os efeitos de sentido que se estabelecem vão na mesma direção da discussão empreendida até aqui.

\section{REFERENCIAS}

BORBA, Mirella Moraes de. Memórias de trabalhadoras da Fábrica Laneira Brasileira S.A.: os lugares silenciosos dos afetos e das dores. 2019. 110f. Dissertação (Programa de PósGraduação em Memória Social e Patrimônio Cultural). Pelotas, Universidade Federal de Pelotas, 2019.

CARVALHO, Frederico F. C. Discurso, Resistência e Sujeito. In: SOARES, Alexandre S. Ferrari; MARIANI, Bethania; DELA SILVA, Silmara; MEDEIROS, Vanise (Orgs.). Discurso, resistência e.... Cascavel: EDUNIOESTE, 2015.

ENGELS, Friedrich. A situação da classe trabalhadora na Inglaterra. Boitempo editorial, São Paulo, 2010.

ESSINGER, Cíntia Vieira. Entre a fábrica e a rua: a companhia fiação e tecidos pelotenses e a criação do espaço operário. Bairro da Várzea, Pelotas, RS (1953-1974). Dissertação (Programa de Pós-Graduação em Memória Social e Patrimônio Cultural). Pelotas, Universidade Federal de Pelotas, 2009.

INDURSKY, Freda. Da interpelação à falha no ritual: a trajetória teórica da noção de formação discursiva. In: BARONAS, Roberto Leiser (Org.). Análise de discurso: 
apontamentos para uma história da noção-conceito de formação discursiva. São Carlos: Pedro \& João Editores, 2007, p. 75-88.

MARX, Karl; BOLTE, Friedrich. In: Obras escolhidas. 23 de novembro de 1871. Vol. 3. São Paulo: Alfa Ômega, S/D.

ORLANDI, Eni P. O próprio da Análise do Discurso. Série Escritos, n. 3. Campinas: LABEURB/UNICAMP, 1998.

ORLANDI, Eni P. Discurso em análise: sujeito, sentido e ideologia. Campinas: Pontes, 2012.

ORLANDI, Eni P. Análise de Discurso: princípios e procedimentos. 12ª Edição. Campinas, SP: Pontes, 2015.

PÊCHEUX, Michel. Delimitações, inversões, deslocamentos. Cadernos de Estudos Linguísticos, n. 19, p. 7-24, 1990.

PÊCHEUX, Michel. Metáfora e interdiscurso. In: Análise de Discurso: Michel Pêcheux. Textos selecionados: Eni Puccinelli Orlandi. Campinas, SP: Pontes Editores, 2011.

PÊCHEUX, Michel. O Discurso: estrutura ou acontecimento. Trad. Eni P. Orlandi. $6^{\underline{a}}$ ed. Campinas: Pontes, 2012.

PÊCHEUX, Michel. Ousar pensar e ousar se revoltar: ideologia, marxismo, luta de classes. Décalages, v. 1, n. 4, 2014. Tradução: Guilherme Adorno e Gracinda Ferreira.

PÊCHEUX, Michel. Semântica e discurso: uma crítica à afirmação do óbvio. Tradução de Eni P. Orlandi. 5. ed. Campinas, SP: Editora da Unicamp, 2018.

Nota do editor:

Artigo submetido para avaliação em: 30 de setembro de 2020.

Aprovado em sistema duplo cego em: 03 de março de 2021. 